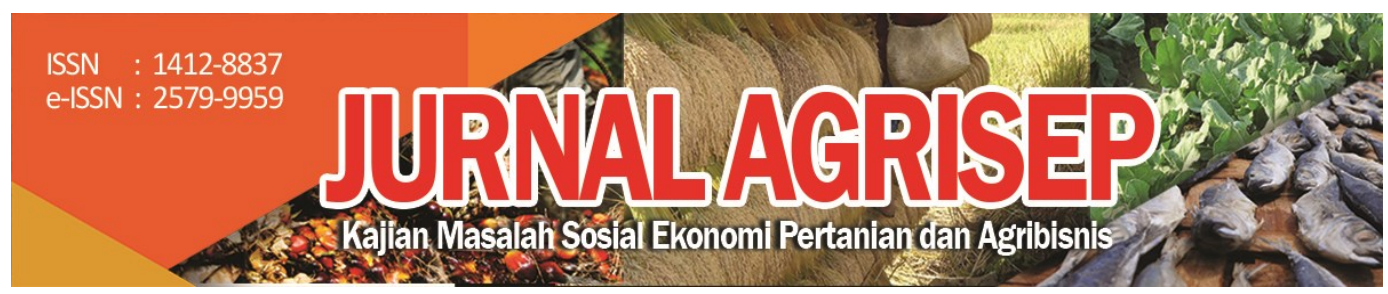

DOI: 10.31186/jagrisep.20.2.381-396

\title{
ANALYSIS OF INDONESIAN COFFEE EXPORT PERFORMANCE TO THE GLOBAL MARKET USING VECTOR AUTOREGRESSION (VAR) APPROACH
}

\author{
Fadhlan Zuhdii); Nola Windirah") ${ }^{2)}$; dan Achmad Subchiandi Maulana ${ }^{3)}$ \\ 1) Assessment Institute of Agriculture Technology Riau, Riau, Indonesia \\ 2) Agribusiness Study Program, Faculty of Agriculture, University of Bengkulu, \\ Bengkulu, Indonesia \\ 3) Agribusiness Study Program, Faculty of Agriculture, University of Timor, \\ Nusa Tenggara Timur, Indonesia \\ Email: nolawindirah@unib.ac.id
}

\begin{abstract}
Coffee is Indonesia's mainstay export commodity in the plantation sector which has provided a lot of income for Indonesia. Over time, Indonesia's coffee exports have fluctuated due to the impact of globalization and other external factors such as world coffee prices, Indonesian coffee production, the US Dollar exchange rate, Brazilian coffee exports and Colombian coffee exports. Based on this, this study aims to analyze the performance of Indonesian coffee exports to the Global Market using time series data over a period of 29 years using the Vector Autoregression (VAR) approach. The results showed that there were variables that had a short-term and unidirectional relationship with Indonesian coffee exports, namely the US Dollar exchange rate variable, Indonesian coffee production and Brazilian coffee exports.
\end{abstract}

Keywords: Coffee, Export, International Trade, VAR

\begin{abstract}
ABSTRAK
Kopi merupakan komoditas ekspor andalan Indonesia pada sektor perkebunan yang telah banyak memberikan devisa bagi Indonesia. Seiring berjalannya waktu, ekspor kopi Indonesia telah mengalami fluktuasi dikarenakan dampak globalisasi dan faktor eksternal lain seperti harga kopi dunia, produksi kopi Indonesia, nilai tukar Dollar Amerika, ekspor kopi Brazil dan ekspor kopi Kolombia. Berdasarkan hal tersebut, penelitian ini bertujuan untuk menganalisis kinerja ekspor kopi Indonesia ke Pasar
\end{abstract}


Global dengan menggunakan data time series dengan kurun waktu 29 tahun menggunakan pendekatan Vector Autoregression (VAR). Hasil penelitian menunjukkan bahwa terdapat variabel yang memiliki hubungan jangka pendek dan searah dengan ekspor kopi Indonesia yaitu variabel nilai tukar Dollar Amerika, produksi kopi Indonesia dan ekspor kopi Brazil.

Kata kunci: kopi, ekspor, perdagangan internasional, VAR

\section{INTRODUCTION}

The Indonesian economy increased by 5.05 percent in the third quarter of 2020 based on the amount of Gross Domestic Product (GDP) at current prices. The component of goods and services exports became the component with the deepest contraction of 7.52 percent as the expenditure side of the economic growth indicator (Central Statistics Agency, 2020a). The World Bank predicts Indonesia's economy will grow positively 4.4 percent in 2021, even though growth is still overshadowed by the impact of the Covid-19 pandemic. Economic theory explains that trade factors (exports and imports) are one of the important indicators in determining economy of a country, in addition to factors of consumption, investment and government spending. Rinaldi et al., (2017), Asbiantari et al., (2016), Nopeline and Simanjuntak (2017) found that there was a significant effect of international trade activities on a country's economic growth.

Types of non-oil and gas exports are grouped into 4 sectors in Indonesia, namely the agricultural sector, processing industry, mining and others. The best development in non-oil and gas exports lies in the agricultural sector with positive growth of 14.03 percent in 2020. Meanwhile, the manufacturing sector grew positively by 2.94 percent, the mining sector grew negatively by 20.70 percent, and other sectors grew negatively 25.49 . percent. The coffee commodity is one of the largest contributors to the non-oil and gas exports of the Indonesian agricultural sector, where the coffee export rate has experienced a positive growth of 6.29 percent in 2020 (Ministry of Trade, 2020). The movement of the curve of the volume and value of Indonesian coffee exports has varied considerably since the last 10 years. The highest volume occurred in 2013 with a total of 532.1 thousand tons and an export value of US\$ 1.2 billion. Meanwhile, the lowest volume in 2018 was 277.4 thousand tons and the export value was US\$ 806.9 million. In 2019, it increased again to 355.8 thousand tons with an export value of US\$ 872.4 million and it was recorded that in July 2020 it had stepped on 186.8 thousand tons with an export value of US\$ 435.3 million (Central Statistics Agency, 2020b)

The movement of the Indonesian coffee export curve is certainly influenced by various factors, including the Dollar exchange rate, Indonesian coffee production, and the number of coffee exports from competing countries 
(Haryadi \& Nopriyandi, 2017; Lo, 2014; Sari et al., 2016; Desnky et al., 2018). Based on the description above, it is very important to reexamine the renewal of the influence magnitude of several factors such as the Dollar exchange rate, Indonesian coffee production, and the number of coffee exports from competing countries (Brazil and Colombia) on the development of Indonesian coffee exports in 2021.

\section{METHODS}

This study used data on Indonesian coffee exports, world coffee prices, Indonesian coffee production, US Dollar exchange rates, Brazilian coffee exports, and Colombian coffee exports. The data used for this research started from 1991 to 2019 which were obtained from various sources, namely FAOSTAT, Investing and Trademap.

The analysis technique used to forecast coffee exports is Vector Autoregression (VAR). The VAR model is often used to search for the habitual form of a variable over time in a sustainable manner (Hamzah et al., 2020). The VAR equation model was first used by Sims in 1980 as a tool for analyzing macroeconomic data where VAR analysis is a modification or combination of multivariate regression using time series data (Zuhroh et al., 2017). The VAR analysis technique treats all variables symmetrically, which means that there are no dependent variables. In the VAR model, a vector consists of two or more variables and on the right hand side contains the lag vector of the dependent variable. Mathematically the VAR model can be written as follows:

$$
\begin{aligned}
\ln Q_{t}= & \alpha+\beta_{1} \ln E R_{t-1}+\beta_{2} \ln H K_{t-1}+\beta_{3} \ln P K_{t-1}+\beta_{4} \ln E K I_{t-1}+ \\
& \beta_{5} \ln P C_{t-1}+\varepsilon_{t}
\end{aligned}
$$

where $\mathrm{Q}$ is the Indonesian coffee export (tons), ER is the world coffee price (US\$/ton), HK is the Indonesian coffee production (tons), PK is the US Dollar exchange rate, EKI is the Brazilian coffee export (ton), EKC is a Colombian coffee export (ton).

The steps taken to estimate the VAR model are as follows: (1) data stationarity test; (2) cointegrity test; and (3) optimum lag test. Furthermore, the analyzes used in the VAR model are as follows: (1) causality test; (2) impulse response factor; and (3) variance decomposition (Ekananda, 2016; Sutawijaya and Lestari, 2013; Sulistiana et al, 2017).

The Granger Causality Test is carried out to see the effect between variables where the test is carried out only to see the relationship between variables and not to estimate the model (Hafidh, 2011). The steps for carrying out the Granger causality test are as follows: (1) regressing two variables by entering several lags so that the value of Restricted Residual Sum of Square (SSRR) and Unrestricted Residual Sum of Square (SSRU) which then used to see F-value calculated; (2) testing the hypothesis in which if the calculated F-value is greater than the F- 
table value, $\mathrm{H} 0$ is rejected, which means that there is a causality relationship between variables; (3) the same steps are repeated for other variables with different lags (Suharjon et al., 2018). Impulse Response Function (IMF) is used to see the effect of shock on variables will be presented in graphical form and each variable contribution is described in Variable Decomposition which is presented in tabular form.

\section{RESULT AND DISCUSSION}

\section{Unit Root Test}

The first step in VAR testing is to perform a stationary test or unit root test using the Augmented Dicky Fuller (ADF) method. The ADF test was carried out to determine the stationarity of the data used in the study by looking at the ADF value which was then compared with a significance level of 5 percent (0.05). Initially, the research data was carried out by ADF testing at the level stage, but if the data was still not stationary then the next derivative was used, namely 1 st difference or 2nd difference.

Criteria used is if the prob value is greater than 0.05 then accept $\mathrm{H}_{0}$ and if the prob value is less than 0.05 then accept $\mathrm{H}_{1}$. Furthermore, the unit root test results are presented in Table 1. The major findings can be briefly highlighted at the beginning of this section, but the results should not be repeated. Instead, they should be interpreted using logic and previously published articles.

Table 1. Unit Root Test Results

\begin{tabular}{lcccccc}
\hline \multirow{2}{*}{ Stage } & \multicolumn{7}{c}{ Probability Value } \\
\cline { 2 - 7 } & LN_ER & LN_HK & N_PK & N_EKI & N_EKB & LN_EKC \\
\hline Level & 0.4295 & 0.2186 & 0.6699 & 0.0118 & 0.6660 & 0.4111 \\
$1^{\text {st }}$ difference & 0.0001 & 0.0002 & 0.0002 & 0.0000 & 0.0013 & 0.0007 \\
\hline
\end{tabular}

Source: Processes Secondary Data, 2021

Based on the results of the unit root test, it appears that the variable does not show the level of stationary phase so that should be further tested in the 1st difference stage. Testing with the 1st difference method shows that the data has been stationary with a significance level of 5 percent. Hence, a variable with 1st difference which will then be used to perform VAR analysis

\section{Cointegration Test}

The second stage in conducting VAR analysis is to test cointegration using the Johansen-Cointegration Test. The cointegration test is carried out to determine whether or not there is a long-term relationship between the variables used by comparing critical values and trace statistics. 
The criteria used are if the value of trace statistics is smaller than the critical value then accept $\mathrm{H}_{0}$ and if the value of trace statistics greater than the critical value then accept $\mathrm{H}_{1}$.

Based on the results of the Johansen-Cointegration Test, it can be seen that each variable has cointegration because it has a trace statistics value that is greater than the critical value at the significance level of 5 percent $(0.05)$ and 10 percent $(0.10)$. Furthermore, the results of the Johansen-Cointegration Test are presented in Table 2.

Table 2. Results of the Johansen-Cointegration Test

\begin{tabular}{cccc}
\hline Alpha & Critical Value & Trace Statistics & Cointegration \\
\hline $5 \%$ & 95.75366 & 124.2553 & Cointegrated \\
$10 \%$ & 91.11028 & 124.2553 & Cointegrated \\
\hline
\end{tabular}

Source: Processes Secondary Data, 2021

\section{Optimum Lag Test Results}

The optimum lag test results were performed after conducting the cointegration test. This test is conducted to determine the extent to which the time span affects the variables. In the optimum lag test, there are several approaches to be assessed, namely Likelihood Ratio (LR), Final Prediction Error (FPE), Akaike Information Criterion (AIC), Scharz Information Criterion (SIC) and Hannam Quinn (HQ). Based on the test results, it is known that the optimum lag produced is lag 3 because the majority of the approach indicators show the maximum lag is at lag 3, namely FPE, AIC, SC and HQ, while the LR approach chooses lag 1 . Here are the results of the optimum lag test presented in Table 3.

Table 3. Results of optimum lag test

\begin{tabular}{ccccccc}
\hline Lag & LogL & LR & FPE & AIC & SC & HQ \\
\hline 0 & 37.33792 & NA & $3.62 \mathrm{e}-09$ & -2.410609 & -2.120279 & -2.327005 \\
1 & 122.8876 & $125.0342^{*}$ & $8.68 \mathrm{e}-11$ & -6.222123 & -4.189814 & -5.636892 \\
2 & 164.6217 & 41.73410 & $9.30 \mathrm{e}-11$ & -6.663208 & -2.888919 & -5.576349 \\
3 & 256.7498 & 49.60742 & $7.53 \mathrm{e}-12^{*}$ & $-10.98075^{*}$ & $-5.464483^{*}$ & $-9.392266^{*}$ \\
\hline
\end{tabular}

Source: Processes Secondary Data, 2021

\section{VAR Estimation}

Further stage analysis is to estimate Autoregression Vector (VAR) to each variable. VAR estimation is used to see the influence of variable $X$ on variable $Y$ by comparing the value of $t$ calculated and $t$ table (2.04847). The criteria used is 
if the value of $\mathrm{t}$ calculated $>$ of 2.04847 or $<-2.04847$ then reject $\mathrm{H}_{0}$ and if $\mathrm{t}$ calculated < of 2.04847 or $>-2.04847$ then accept $\mathrm{H}_{0}$.

Based on the VAR estimation results, it is known that the Indonesian Coffee Export variable D (LNEKI) is directly influenced by D (LNHK) or world coffee prices where the $t$-calculated D $(\operatorname{LNHK}(-3))=2.04894$ or less than the $t$ table value. Furthermore, the Indonesian coffee production variable D (LNPK ($3)$ ), the US Dollar exchange rate variable D (LNER (-1)) and D (LNER (-3)) and the Brazilian coffee export variable D (LNEKB (-2)) has a significant influence on Indonesian coffee exports because it has a calculated $t$ value that is included in the reject $\mathrm{H} 0$ hypothesis. Each independent variable has a calculated $t$ value of $\mathrm{D}$ $(\operatorname{LNPK}(-3))=3.01621, \mathrm{D}(\operatorname{LNER}(-1))=2.70972, \mathrm{D}(\operatorname{LNER}(-3))=-3.36658$ and D $(\operatorname{LNEKB}(-2))=2.60621$. Based on this, the VAR model that can be written is as follows:

$$
\begin{aligned}
\mathrm{D}(\operatorname{lnEKI}) & =0.284629 \ln H K(-3)-2.431077 \ln P K(-3+0.423164 \ln E R(-1) \\
& -0.822040 \operatorname{lnER}(-3)+0.975307 \operatorname{lnEKB}(-2)
\end{aligned}
$$

The VAR model that has been created based on the estimation results can be interpreted that Indonesian coffee exports in the current year could increase by 0.284629 tons if there was an increase in world coffee prices per ton in the previous three years. In addition, if there was an increase in Indonesian coffee production in the previous three years by one ton, then will reduce Indonesia's coffee exports in the current year by 2.431077 tons.Furthermore, an increase in the value of the rupiah per one US Dollar in the previous year will increase Indonesia's coffee exports by 0.423164 tons in the current year and an increase in the value of the rupiah per one US Dollar in the previous three years will reduce Indonesia's coffee exports amounted to 0.822040 tons in the current year. Brazilian coffee exports of 1 ton in the previous two years will cause an increase in Indonesian coffee exports by 0.975307 tonnes in the current year. The following is the VAR estimation results presented in Table 4.

Table 4. VAR Estimation Results

\begin{tabular}{ccccccc}
\hline Variable & $\mathrm{D}(\mathrm{LNEKI})$ & $\mathrm{D}(\mathrm{LNHK})$ & $\mathrm{D}(\mathrm{LNPK})$ & $\mathrm{D}(\mathrm{LNER})$ & $\mathrm{D}(\mathrm{LNEKB})$ & $\mathrm{D}(\mathrm{LNEKC})$ \\
\hline $\mathrm{D}($ LNEKI$(-1))$ & -0.845583 & 0.497726 & -0.073826 & -0.016457 & 0.094649 & -0.125596 \\
& $(0.16142)$ & $(0.22660)$ & $(0.11282)$ & $(0.43654)$ & $(0.12409)$ & $(0.10059)$ \\
& {$[-5.23838]$} & {$[2.19648]$} & {$[-0.65436]$} & {$[-0.03770]$} & {$[0.76275]$} & {$[-1.24862]$} \\
$\mathrm{D}($ LNEKI(-2)) & -0.467041 & 0.444649 & -0.079185 & 0.407816 & 0.300705 & 0.411776 \\
& $(0.21096)$ & $(0.29615)$ & $(0.14745)$ & $(0.57051)$ & $(0.16217)$ & $(0.13146)$ \\
& {$[-2.21386]$} & {$[1.50144]$} & {$[-0.53704]$} & {$[0.71482]$} & {$[1.85421]$} & {$[3.13236]$} \\
$\mathrm{D}($ LNEKI(-3)) & -0.275239 & 0.465429 & -0.119468 & -0.401078 & 0.155655 & 0.099415 \\
& $(0.18658)$ & $(0.26193)$ & $(0.13041)$ & $(0.50459)$ & $(0.14343)$ & $(0.11627)$
\end{tabular}

386 | Fadhlan Zuhdi, Nola Windirah dan Achmad S. Maulana: Analysis.. 


\begin{tabular}{|c|c|c|c|c|c|c|}
\hline & [-1.47514] & [ 1.77695] & {$[-0.91610]$} & {$[-0.79486]$} & [ 1.08521$]$ & [ 0.85505] \\
\hline \multirow[t]{3}{*}{ D(LNHK(-1)) } & -0.072474 & -0.193880 & 0.055394 & 0.057107 & -0.311415 & -0.432265 \\
\hline & $(0.16202)$ & $(0.22744)$ & $(0.11324)$ & $(0.43815)$ & $(0.12455)$ & (0.10096) \\
\hline & {$[-0.44732]$} & {$[-0.85246]$} & [ 0.48918] & [ 0.13034] & [-2.50037] & [-4.28160] \\
\hline \multirow[t]{3}{*}{ D(LNHK(-2)) } & 0.090805 & -0.148282 & -0.071130 & 0.168367 & -0.064236 & 0.063440 \\
\hline & (0.19749) & $(0.27723)$ & $(0.13803)$ & $(0.53408)$ & $(0.15182)$ & $(0.12306)$ \\
\hline & [ 0.45980] & {$[-0.53486]$} & {$[-0.51532]$} & [ 0.31525$]$ & {$[-0.42312]$} & [ 0.51551] \\
\hline \multirow[t]{3}{*}{ D(LNHK(-3)) } & 0.284629 & 0.286736 & -0.049197 & -0.100200 & -0.035121 & -0.035809 \\
\hline & (0.13892) & $(0.19501)$ & $(0.09709)$ & $(0.37567)$ & $(0.10679)$ & $(0.08656)$ \\
\hline & [ 2.04894] & [ 1.47038] & {$[-0.50671]$} & {$[-0.26672]$} & {$[-0.32889]$} & [-0.41367] \\
\hline \multirow[t]{3}{*}{ D(LNPK(-1)) } & -0.806656 & -0.493118 & -0.125668 & -0.027700 & 0.050118 & 0.352438 \\
\hline & $(0.64989)$ & $(0.91231)$ & $(0.45423)$ & $(1.75752)$ & $(0.49959)$ & $(0.40497)$ \\
\hline & [-1.24122] & {$[-0.54052]$} & {$[-0.27666]$} & {$[-0.01576]$} & [ 0.10032] & [ 0.87028] \\
\hline \multirow[t]{3}{*}{ D(LNPK(-2)) } & 0.812247 & 1.402491 & -0.453324 & -1.673877 & 0.323086 & -0.786584 \\
\hline & $(0.63012)$ & $(0.88456)$ & $(0.44041)$ & $(1.70406)$ & $(0.48439)$ & $(0.39265)$ \\
\hline & [ 1.28904] & [ 1.58553] & [-1.02933] & [-0.98229] & [ 0.66699] & {$[-2.00326]$} \\
\hline \multirow[t]{3}{*}{ D(LNPK(-3)) } & 2.431077 & 0.748166 & -0.494661 & 0.799911 & 0.237184 & 1.308989 \\
\hline & $(0.80601)$ & $(1.13146)$ & $(0.56334)$ & $(2.17971)$ & $(0.61960)$ & $(0.50225)$ \\
\hline & [ 3.01621] & [ 0.66124] & [-0.87809] & [ 0.36698] & [ 0.38280] & [ 2.60623] \\
\hline \multirow[t]{3}{*}{ D(LNER(-1)) } & 0.423164 & -0.257239 & 0.063988 & & 0.208461 & -0.176230 \\
\hline & $(0.15617)$ & $(0.21922)$ & $(0.10915)$ & $(0.42232)$ & $(0.12005)$ & $(0.09731)$ \\
\hline & [ 2.70972] & {$[-1.17341]$} & [ 0.58625] & [ 0.05623] & [ 1.73646$]$ & [-1.81097] \\
\hline \multirow[t]{3}{*}{ D(LNER(-2)) } & 0.036505 & -0.603878 & 0.050984 & 0.319978 & -0.277403 & 0.179461 \\
\hline & (0.19003) & $(0.26677)$ & $(0.13282)$ & $(0.51391)$ & (0.14609) & $(0.11842)$ \\
\hline & [ 0.19210] & {$[-2.26369]$} & [ 0.38386] & [ 0.62263$]$ & {$[-1.89891]$} & [ 1.51550$]$ \\
\hline \multirow[t]{3}{*}{$\mathrm{D}(\operatorname{LNER}(-3))$} & -0.822040 & -0.663035 & 0.133101 & 0.290061 & 0.003305 & -0.346452 \\
\hline & $(0.24418)$ & $(0.34277)$ & $(0.17066)$ & $(0.66034)$ & $(0.18771)$ & $(0.15216)$ \\
\hline & {$[-3.36658]$} & [-1.93433] & [ 0.77991] & [ 0.43926$]$ & [ 0.01761] & [-2.27696] \\
\hline \multirow[t]{3}{*}{$\mathrm{D}(\mathrm{LNEKB}(-1))$} & -0.642750 & 0.583241 & 0.128907 & -0.173902 & -0.206471 & -0.777651 \\
\hline & $(0.44719)$ & $(0.62776)$ & $(0.31255)$ & $(1.20935)$ & $(0.34377)$ & $(0.27866)$ \\
\hline & {$[-1.43732]$} & [ 0.92909] & [ 0.41243] & {$[-0.14380]$} & {$[-0.60061]$} & [-2.79068] \\
\hline \multirow[t]{3}{*}{$\mathrm{D}(\mathrm{LNEKB}(-2))$} & 0.975307 & 0.542121 & -0.173198 & -0.107801 & -0.257536 & 0.326434 \\
\hline & $(0.37422)$ & $(0.52533)$ & $(0.26156)$ & $(1.01203)$ & $(0.28768)$ & $(0.23319)$ \\
\hline & [ 2.60621] & [ 1.03196] & {$[-0.66218]$} & {$[-0.10652]$} & {$[-0.89522]$} & [ 1.39984] \\
\hline
\end{tabular}




\begin{tabular}{|c|c|c|c|c|c|c|}
\hline \multirow[t]{2}{*}{$\mathrm{D}(\mathrm{LNEKB}(-3))$} & $\begin{array}{r}-0.002213 \\
(0.27082)\end{array}$ & $\begin{array}{r}-0.155619 \\
(0.38018)\end{array}$ & $\begin{array}{l}0.178807 \\
(0.18928)\end{array}$ & $\begin{array}{r}-0.226365 \\
(0.73239)\end{array}$ & $\begin{array}{r}-0.275127 \\
(0.20819)\end{array}$ & $\begin{array}{r}-0.258774 \\
(0.16876)\end{array}$ \\
\hline & [-0.00817] & {$[-0.40934]$} & [ 0.94465] & {$[-0.30908]$} & [-1.32153] & [-1.53340] \\
\hline \multirow[t]{3}{*}{ D(LNEKC(-1)) } & 0.235157 & -0.162887 & -0.044323 & 0.833220 & -0.105138 & 0.823820 \\
\hline & $(0.44393)$ & $(0.62318)$ & $(0.31027)$ & $(1.20052)$ & $(0.34126)$ & $(0.27663)$ \\
\hline & [ 0.52972] & {$[-0.26138]$} & {$[-0.14285]$} & [ 0.69405$]$ & {$[-0.30809]$} & [ 2.97809] \\
\hline \multirow[t]{3}{*}{ D(LNEKC(-2)) } & 0.336187 & -0.812941 & 0.097357 & -0.063348 & 0.010054 & -0.330941 \\
\hline & $(0.36234)$ & $(0.50865)$ & $(0.25325)$ & $(0.97989)$ & $(0.27854)$ & $(0.22579)$ \\
\hline & [ 0.92782] & {$[-1.59822]$} & [ 0.38443] & {$[-0.06465]$} & [ 0.03609] & {$[-1.46571]$} \\
\hline \multirow[t]{3}{*}{ D(LNEKC(-3)) } & -0.435624 & 0.906322 & -0.132224 & -0.703534 & -0.212661 & -0.191041 \\
\hline & $(0.25518)$ & $(0.35822)$ & $(0.17835)$ & $(0.69010)$ & $(0.19617)$ & $(0.15901)$ \\
\hline & {$[-1.70711]$} & [ 2.53005] & {$[-0.74136]$} & [-1.01947] & {$[-1.08408]$} & [-1.20142] \\
\hline \multirow[t]{3}{*}{ C } & -0.001220 & 0.037282 & 0.022151 & 0.049151 & 0.048475 & 0.033381 \\
\hline & $(0.04492)$ & $(0.06305)$ & $(0.03139)$ & $(0.12147)$ & $(0.03453)$ & $(0.02799)$ \\
\hline & {$[-0.02716]$} & [ 0.59128] & [ 0.70561] & [ 0.40463] & [ 1.40391] & [ 1.19264] \\
\hline $\mathrm{R}^{2}$ & 0.929677 & 0.877144 & 0.516217 & 0.529651 & 0.867946 & 0.870953 \\
\hline Adj. $R^{2}$ & 0.718706 & 0.508574 & -0.935132 & -0.881396 & 0.471783 & 0.483811 \\
\hline SSR & 0.104960 & 0.206838 & 0.051273 & 0.767621 & 0.062026 & 0.040756 \\
\hline S.E. equation & 0.132263 & 0.185669 & 0.092442 & 0.357683 & 0.101675 & 0.082418 \\
\hline F-statistic & 4.406671 & 2.379862 & 0.355681 & 0.375360 & 2.190880 & 2.249699 \\
\hline Log likelihood & 32.93965 & 24.46022 & 41.89481 & 8.068229 & 39.51491 & 44.76431 \\
\hline AIC & -1.115172 & -0.436818 & -1.831585 & 0.874542 & -1.641193 & -2.061145 \\
\hline $\mathrm{SC}$ & -0.188827 & 0.489528 & -0.905239 & 1.800887 & -0.714847 & -1.134799 \\
\hline Mean dependent & 0.008400 & -0.013600 & 0.020800 & 0.075200 & 0.037200 & 0.005200 \\
\hline
\end{tabular}

Source: Processes Secondary Data, 2021

\section{Causality Test}

The next stage to find out whether there is a one-way or two-way relationship in a variable with other variables is to do the Granger causality test. The Granger causality test is carried out by comparing the calculated F value with the $\mathrm{F}$ table (2.6612) by paying attention to the probability value first (prob $<0.05$ ). The criteria used is if the value of $f$ calculated $>$ than 2.6612 then reject $\mathrm{H} 0$ and if $\mathrm{t}$ calculated < from 2.6612 then accept H0. Furthermore, the results of the Granger causality test are presented in Table 5.

388 | Fadhlan Zuhdi, Nola Windirah dan Achmad S. Maulana: Analysis.. 
Table 5. The results of the Granger causality test

\begin{tabular}{lccc}
\hline \multicolumn{1}{c}{ Indicator } & F Calculated & Probability & Causality \\
\hline LNEKI - LNER & 0.02508 & 0.8754 & N/A \\
LNER t - LNEKI & 4.62308 & 0.0414 & Applicable \\
LNEKI - LNHK & 3.38723 & 0.0776 & N/A \\
LNHK - LNEKI & 2.73989 & 0.1104 & N/A \\
LNEKI - LNPK & 0.20966 & 0.6510 & N/A \\
LNPK - LNEKI & 5.57442 & 0.0263 & Applicable \\
LNEKI - LNEKB & 0.22733 & 0.6377 & N/A \\
LNEKB - LNEKI & 7.25811 & 0.0124 & Applicable \\
LNEKI - LNEKC & 0.08495 & 0.7731 & N/A \\
LNEKC - LNEKI & 1.34660 & 0.2568 & N/A \\
\hline
\end{tabular}

Source: Processes Secondary Data, 2021

Based on the results of the Granger causality test, it can be seen that there is a direct relationship between the US Dollar exchange rate variable (LNER) and the Indonesia coffee export variable (LNEKI). This is confirmed based on the probability value on the LNER indicator against LNEKI with a probability value of 0.0414 and a calculated $f$ value that exceeds the $f$ table (4.62308). Thus, it can be said that changes in the US Dollar exchange rate variable are predicted to affect the export value of Indonesian coffee, but this does not apply otherwise. In addition, another variable that has a unidirectional relationship is the variable of Indonesian coffee production (LNPK) to Indonesian coffee exports (LNEKI). This is confirmed based on the probability value which is lower than the significance level of 0.0263 and the calculated $\mathrm{f}$ value is greater than the $\mathrm{f}$ table which is equal to 5.57442 . Thus it can be said that changes in Indonesian coffee production are predicted to affect Indonesian coffee exports.

Other variables that have an unidirectional relationship are the variable Brazilian coffee exports (LNEKB) and Indonesian coffee exports (LNEKI) where this is confirmed based on a probability value that is smaller than the significance level of 0.0124 and the calculated $f$ value is greater than the $f$ table, which is equal to 7,25811 . This indicates that changes in Brazilian coffee exports are predicted to affect Indonesian coffee exports. Alexander \& Nadapdap (2019) in their research found that there is a competitive and comparative advantage to Indonesian coffee in the world, so that Indonesian coffee is able to compete with the world's largest coffee exporting country such as Brazil. Even Indonesian coffee is in aposition rising star in the destination country for coffee exports, namely the USA (Manalu et al., 2019; Hamzah et al., 2020). 


\section{Impulse Respon Function}

The next stage that is carried out after conducting the optimum lag test is the Impulse Response Function (IRF). In the VAR test, IRF is carried out to determine the response given by a dependent variable when there is shock from the independent variable and to see if there is a short or long term relationship that may occur. Based on the results of the Impulse Response Function, it can be seen that the variables of Indonesian Coffee Exports have a short and long term relationship with the variables of the US Dollar Exchange Rate, World Coffee Prices, Brazilian Coffee Production and Exports. The short-term relationship that occurs at the beginning of the period where significant fluctuations occur respectively from period 0 to periods $30,22,30$ and 35 . This indicates that when a shock occurs in one of the independent variables it will respond to Indonesian coffee exports automatically immediately at the beginning of the period and it will take 20 to 35 periods for Indonesian export response to stabilize. However, the same is not the case for the Colombian coffee export variable, which in the long run does not affect Indonesian coffee exports. The response of Indonesian coffee exports to Colombian coffee exports tends to be gentle and only occurs in period 0 to period 10 where this indicates that the relationship occurs only in the short term. The following are the results of the Impulse Response Function of the Indonesian Coffee Export variable which is influenced by other variables as shown in Figure 1.

Aprilla et al., (2012) and Jamilah et al., (2016) explain the influence given by the variable world coffee prices and the US Dollar exchange rate against Indonesian coffee exports. Indonesian coffee exports have the highest comparative advantage in several coffee export destination countries (Ginting \& Kartiasih, 2019; Parnadi, 2018). This underlies the influence of changes in Indonesia's coffee exports to changes in Brazilian exports as the largest exporting country of coffee. 


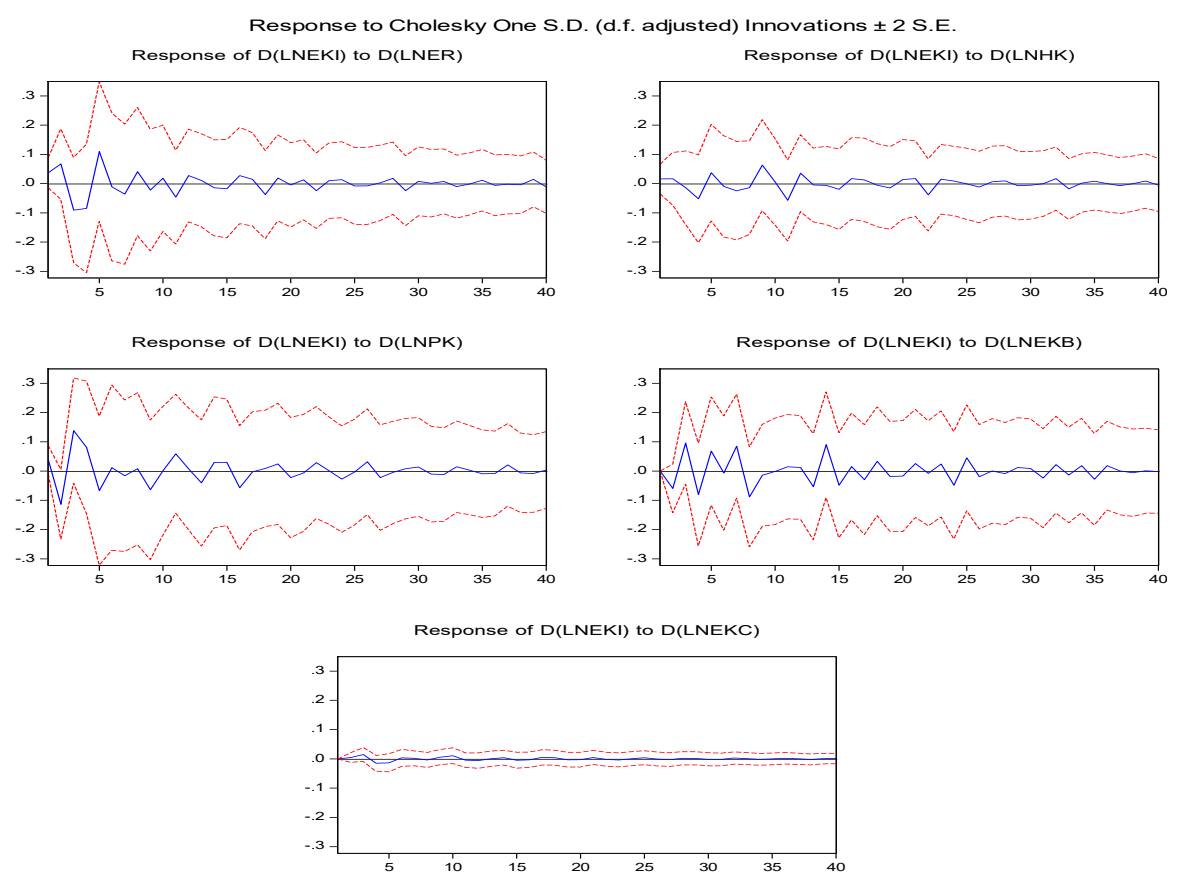

Figure 1

Impulse Response Function of Indonesian Coffee Exports

\section{Variance Decomposition}

The next stage after the impulse response function is variance decomposition where this stage is used to measure the contribution of each variable of the US Dollar exchange rate, world coffee prices, coffee production, Brazilian coffee exports and Colombian coffee exports to Indonesian coffee exports. Based on the results of the variance decomposition, it can be seen that in the first year the contribution of the shock variable to Indonesia's coffee exports is still at a 100 percent level and other variables have not contributed. However, in the second year, the contribution of the US Dollar exchange rate shock experienced a significant increase of up to 20.9 percent followed by an increase in the shock contribution of each variable, namely coffee production by 10.4 percent, Brazilian coffee exports by 6.76 percent, coffee prices by 2.26 and Colombian coffee exports by 2.26 percent. 0.03 percent while the shock contribution of Indonesian coffee exports decreased to 59.56 percent. The shock contribution of each variable continues to fluctuate in each year where in the 20th year, the contribution of the shock to Indonesian coffee exports was only 30.49 percent and the second largest contribution was given by Brazilian coffee exports which reached 22.49 percent. At the end of the analysis year, namely in the 40th year, the biggest shock contribution was still given by Indonesian coffee exports with a contribution of 30.56 percent followed by Brazilian coffee exports at 23.46 percent, Indonesian coffee production at 19.62 percent, US Dollar exchange rate 
of 17.95 percent, prices coffee by 7.99 percent and Colombian coffee exports by 0.39 percent. The results of the analysis show that the contribution of shock has stabilized when entering the 20th year where no fluctuating changes are seen so that the contribution is proportional to the 40th year. Furthermore, the results of the analysis of variance decomposition can be seen in Table 6 .

Table 6. Variance decomposition results

\begin{tabular}{cccccccc}
\hline Year & S.E. & D(LNEKI) & D(LNER) & D(LNHK) & D(LNPK) & D(LNEKB) & D(LNEKC) \\
\hline 1 & 0.132263 & 100.0000 & 0.000000 & 0.000000 & 0.000000 & 0.000000 & 0.000000 \\
2 & 0.227601 & 59.56899 & 20.93939 & 2.264927 & 10.42649 & 6.763675 & 0.036530 \\
3 & 0.300880 & 34.81761 & 20.37586 & 1.513255 & 28.98135 & 14.04983 & 0.262097 \\
4 & 0.345723 & 29.68034 & 24.99136 & 4.520580 & 24.37790 & 16.03421 & 0.395608 \\
5 & 0.382690 & 28.04746 & 26.21867 & 4.379140 & 24.66483 & 16.23728 & 0.452620 \\
6 & 0.388349 & 29.46557 & 25.47917 & 4.256173 & 24.55237 & 15.80002 & 0.446697 \\
7 & 0.400279 & 28.01356 & 24.60273 & 4.347154 & 23.23713 & 19.37730 & 0.422128 \\
8 & 0.417829 & 28.82482 & 22.82904 & 4.265884 & 21.42097 & 22.26378 & 0.395514 \\
9 & 0.430738 & 28.99979 & 21.49784 & 6.698829 & 21.35030 & 21.06411 & 0.389135 \\
10 & 0.434616 & 29.44681 & 21.63110 & 6.659665 & 21.12794 & 20.69049 & 0.444000 \\
11 & 0.444947 & 28.09523 & 21.80226 & 8.132930 & 21.68505 & 19.85071 & 0.433824 \\
12 & 0.456228 & 31.04456 & 20.73767 & 8.019953 & 20.81399 & 18.95348 & 0.430348 \\
13 & 0.464659 & 31.58226 & 20.37900 & 7.737478 & 20.28005 & 19.60631 & 0.414902 \\
14 & 0.475003 & 30.32862 & 19.55117 & 7.414770 & 19.94225 & 22.35933 & 0.403863 \\
15 & 0.480640 & 30.16778 & 19.44878 & 7.515542 & 19.59979 & 22.86440 & 0.403709 \\
16 & 0.485836 & 29.60017 & 19.29197 & 7.470579 & 20.75973 & 22.47855 & 0.398996 \\
17 & 0.488331 & 29.59153 & 19.30947 & 7.510504 & 20.57487 & 22.60746 & 0.406177 \\
18 & 0.492137 & 29.75405 & 19.33178 & 7.396575 & 20.39944 & 22.71266 & 0.405486 \\
19 & 0.496357 & 30.57586 & 19.00849 & 7.465056 & 20.08002 & 22.46784 & 0.402725 \\
20 & 0.497400 & 30.49354 & 18.92973 & 7.528198 & 20.15273 & 22.49194 & 0.403862 \\
21 & 0.499052 & 30.39305 & 18.93660 & 7.633590 & 20.01971 & 22.60709 & 0.409960 \\
22 & 0.502155 & 30.09341 & 18.88216 & 8.111019 & 20.15340 & 22.35424 & 0.405778 \\
23 & 0.505534 & 30.68036 & 18.63938 & 8.032247 & 19.95877 & 22.28378 & 0.405471 \\
24 & 0.509143 & 30.38715 & 18.52268 & 7.971718 & 19.84622 & 22.87241 & 0.399827 \\
25 & 0.512126 & 30.40173 & 18.30765 & 7.882173 & 19.62979 & 23.37816 & 0.400491 \\
26 & 0.514017 & 30.37746 & 18.25808 & 7.910505 & 19.70760 & 23.34856 & 0.397793 \\
27 & 0.514738 & 30.31526 & 18.20705 & 7.899618 & 19.89564 & 23.28319 & 0.399239
\end{tabular}

392 | Fadhlan Zuhdi, Nola Windirah dan Achmad S. Maulana: Analysis.. 


\begin{tabular}{llllllll}
28 & 0.515320 & 30.24969 & 18.31441 & 7.922809 & 19.85248 & 23.26089 & 0.399726 \\
29 & 0.516840 & 30.40048 & 18.30784 & 7.882770 & 19.83136 & 23.17925 & 0.398303 \\
30 & 0.518050 & 30.65595 & 18.22311 & 7.882037 & 19.74480 & 23.09677 & 0.397334 \\
31 & 0.518738 & 30.57478 & 18.17533 & 7.861186 & 19.73961 & 23.25052 & 0.398566 \\
32 & 0.519810 & 30.49053 & 18.14127 & 7.958461 & 19.68169 & 23.32849 & 0.399551 \\
33 & 0.520767 & 30.43901 & 18.09334 & 8.034380 & 19.72544 & 23.30956 & 0.398271 \\
34 & 0.521601 & 30.50638 & 18.05661 & 8.009109 & 19.66866 & 23.36092 & 0.398323 \\
35 & 0.522637 & 30.39090 & 18.02806 & 8.002286 & 19.62708 & 23.55492 & 0.396768 \\
36 & 0.523600 & 30.51767 & 17.96233 & 7.977213 & 19.55519 & 23.59094 & 0.396651 \\
37 & 0.524155 & 30.51671 & 17.93719 & 7.990244 & 19.61903 & 23.54100 & 0.395815 \\
38 & 0.524327 & 30.50687 & 17.93761 & 7.985800 & 19.63452 & 23.53801 & 0.397187 \\
39 & 0.524666 & 30.47269 & 17.98268 & 8.003670 & 19.63632 & 23.50780 & 0.396836 \\
40 & 0.525188 & 30.56316 & 17.95951 & 7.990848 & 19.62774 & 23.46224 & 0.396493 \\
\hline
\end{tabular}

Source: Processes Secondary Data, 2021

The means that can be utilized in order to improve indonesia's coffe competitiveness were productivity and quality increasing based on speciality (Jamil, 2019) and must directly proportional to government policies that continue support the export of Indonesian coffee beans in the global market (Alexander and Nadapdap, 2019). Moreover, The development of the coffee processing industry can be one of the steps to increase the selling value of Indonesian coffee in the world (Sahat et al., 2016).

\section{CONCLUSION}

The Granger causality test shows that there is a direct relationship between the US Dollar exchange rate (LNER) variable and the Indonesian coffee export variable (LNEKI). In addition, other variables that have a unidirectional relationship are the variable of Indonesian coffee production (LNPK) to Indonesian coffee exports (LNEKI) and other variables that have an unidirectional relationship are the variable Brazilian coffee exports (LNEKB) and Indonesian coffee exports (LNEKI). It is said that the changes that occur in these variables are predicted to affect the export value of Indonesian coffee.

Based on the results of the Impulse Response Function, it can be seen that the variables of Indonesian Coffee Exports have a short and long term relationship with the variable of the US Dollar exchange rate, World Coffee Prices, Brazilian Coffee Production and Exports. The short-term relationship that occurs is estimated at the beginning of the period where significant fluctuations occur from period 0 to periods 30,22, 30 and 35. It is different case for the Colombian coffee export variable which in the long run does not affect 
Indonesian coffee exports but the happens only in the short term. Based on the results of the Variance Decomposition, it can be seen that the shock contribution of each variable is quite significant in Indonesian exports at the beginning of the analysis year and continues to vary until the last year of analysis. The results of the analysis show that the contribution of shock has stabilized when entering the 20th year where no fluctuating changes are seen so that the contribution is proportional to the 40th year. with the biggest shock contribution given by Indonesian coffee exports followed by Brazilian coffee exports, Indonesian coffee production, the US Dollar exchange rate, coffee prices and Colombian coffee exports.

\section{REFERENCES}

Alexander, I., \& Nadapdap, H. J. 2019. Analisis Daya Saing Ekspor Biji Kopi Indonesia Di Pasar Global Tahun 2002-2017. JSEP (Journal of Social and Agricultural Economics). 12(2): 1-16.

Aprilla, S., Sukiyono, K., \& Romdhon, M. M. 2012. Efek Instabilitas Nilai Tukar Rupiah Terhadap Penawaran Ekspor Kopi Indonesia Dan Harga Kopi Domestik. Agrisep. 11(1): 51-60.

Asbiantari, D. R. Hutagaol, M. P. Asmara, A. 2016. Pengaruh Ekspor Terhadap Pertumbuhan Ekonomi Indonesia. Jurnal Ekonomi dan Kebijakan Pembangunan. 5(2): 10-31.

Central Statistics Agency. (2020a). Ekonomi Indonesia Triwulan III 2020 Tumbuh 5,05 Persen (q-to- $q)$. Badan Pusat Statistik. https://www.bps.go.id/pressrelease/2020/11/05/1738/ekonomiindonesia-triwulan-iii-2020-tumbuh-5-05-persen--q-to-q-.html

Central Statistics Agency. 2020b. Ekspor Kopi Menurut Negara Tujuan Utama, 2000$2019 . \quad$ Badan Pusat Statistik. https://www.bps.go.id/statictable/2014/09/08/1014/ekspor-kopimenurut-negara-tujuan-utama-2000-2019.html.

Densky, R., Syaparuddin dan Aminah, S. 2018. Ekspor Kopi Indonesia dan Faktor-faktor yang Mempengaruhinya. Jurnal Perdagangan, Industri dan Moneter. 6(1): 23-3.

Ekananda, M. 2016. Analisis Ekonometrika Time Series. Mitra Wacana Media.

Ginting, C. P., \& Kartiasih, F. 2019. Analisis Ekspor Kopi Indonesia Ke NegaraNegara Asean. Jurnal Ilmiah Ekonomi Dan Bisnis. 16(2): 143-157.

Hafidh, A. A. 2011. Analisis Hubungan Pengeluaran Pendidikan dan Pertumbuhan Ekonomi dengan Menggunakan Pendekatan Kausalitas Granger. Jurnal Ekonomi \& Pendidikan. 8(2): 124-141.

Hamzah, L. M., Nabilah, S. U., Russel, E., Usman, M., Virginia, E., \& Wamiliana. 2020. Dynamic Modelling and Forecasting of Data Export of 
Agricultural Commodity by Vector Autoregressive Model. Journal of Southwest Jiaotong University. 55(3): 1-10.

Hamzah, Y. I. G, Ibrahim, J. T, Baroh, I, Mufriantie, F. 2020. Analisis Daya Saing Kopi Indonesia di Pasar Internasional. Agriecobis. 3(1): 17-21.

Haryadi, \& Nopriyandi, R. 2017. Analisis Ekspor Kopi Indonesia. Jurnal Paradigma Ekonomika. 12(1): 192-203.

Jamil, A. S. 2019. Daya Saing Ekspor Kopi Indonesia di Pasar Global. Agriekonomika. 8(1): 26-35.

Jamilah, M., Yulianto, E., \& Mawardi, M. 2016. Pengaruh Nilai Tukar Rupiah, Harga Kopi Internasional dan Produksi Kopi Domestik Terhadap Volume Ekspor Kopi Indonesia (Studi Volume Ekspor Kopi Periode 2009 - 2013). Jurnal Administrasi Bisnis $S 1$ Universitas Brawijaya. 36(1), 58 64.

Lo, L. 2014. Analisis Faktor-Faktor yang Mempengaruhi Ekspor Kopi Indonesia ke Amerika Serikat Periode 2002-2013. Calyptra: Jurnal Ilmiah Mahasiswa Universitas Surabaya. 6(1): 1572-1596.

Manalu, D. S. T., Harianto, H., Suharno, S., \& Hartoyo, S. (2019). Posisi Daya Saing dan Kinerja Ekspor Kopi Indonesia di Pasar Global. Jurnal Ekonomi Pertanian Dan Agribisnis. 3(4): 830-839.

Ministry of Trade. 2020. Perkembangan Ekspor NonMigas (Sektor). Kementerian Perdagangan. https://statistik.kemendag.go.id/growth-of-non-oiland-gas-export-sectoral.

Nopeline, N. dan Simanjuntak, A. K. 2017. Analisis Pengaruh Ekspor Terhadap Pertumbuhan Ekonomi Indonesia Periode 2000 - 2016. Majalah Ilmiah Politeknik Mandiri Bina Prestasi. 6(1): 111-123.

Parnadi, F. 2018. Analisis Daya Saing Ekspor Kopi Indonesia di Pasar Internasional. Jurnal Manajemen Bisnis dan Kewirausahaan. 2(4): 52-61.

Rinaldi, M., Jamal, A., \& Seftarita, C. 2017. Analisis Pengaruh Perdagangan Internasional Dan Variabel Makro Ekonomi Terhadap Pertumbuhan Ekonomi Indonesia. Jurnal Ekonomi Dan Kebijakan Publik Indonesia. 4(1): 49-62.

Sahat, S. F., Nuryartono, N., Hutagaol, M. P. 2016. Analisis Pengembangan Ekspor Kopi Indonesia. Jurnal ekonomi dan Kebijakan Pembangunan. 5(1): 63-89.

Sari, D. R., Tety, E., \& Eliza. 2016. Analisis Posisi Ekspor Kopi Indonesia Di Pasar Dunia. Jom Faperta. 3(1): 1-7.

Suharjon, N., Marwanti, S., \& Irianto, H. 2018. Pengaruh Ekspor, Impor, dan Investasi terhadap Pertumbuhan Sektor Pertanian Indonesia. Jurnal Agro Ekonomi. 35(1): 49-65.

Sulistiana, I. Hidayati. Sumar. 2017. Model Vector Auto Regression (VAR) and Vector Error Correction Model (VECM) Approach for Inflation Relations Analysis, Gross Regional Domestic Product (GDP), World Tin 
Price, Bi Rate and Rupiah Exchange Rate. Integrated Journal of Business and Economics. 1(2): 17-32.

Sutawijaya, A. Lestari, E. P. 2013. Penerapan Metode Vector Auto Regression Dalam Interaksi Kebijakan Fiskal Dan Moneter di Indonesia. Jurnal Ekonomi Pembangunan. 14(1): 66-77.

Zuhroh, I., Kusuma, H., \& Kurniawati, S. 2017. An Approach of Vector Autoregression Model for Inflation Analysis in Indonesia. Journal of Economics, Business \& Accountancy Ventura. 20(3): 261-268. 